\title{
Naxis
}

Anna Lewenstam

\section{„My nie jesteśmy: ty i ja. My jesteśmy czegoś katastrofalną tylko konsekwencją"*. Maria Jehanne Wielopolska pisze historię kobiet}

wój artykuł poświęcam wybranym utworom Marii Wielopolskiej, których akcja
zostaje osadzona w czasach Rzeczypospolitej szlacheckiej. Autorka buduje tu nową
wizję I Rzeczypospolitej, a proces rozliczeń z istniejącą wersją historii Wielopolska roz-
poczyna od czasów panowania Zygmunta I Starego i Zygmunta II Augusta, osadzając
tym samym akcję swoich utworów - Sobole i Kontryfatowe lichtarze u świętej Agnieszki -
w wieku XVI, w Złotym Wieku Rzeczypospolitej. Swoją panoramę historyczną kończy
natomiast na dziejach upadku państwa polskiego, a więc na wieku XVIII, któremu
poświęcony jest tekst Napis na furtce ${ }^{1}$ Dzięki ukazaniu dwóch skrajnych momentów
w historii Polski — jej rozkwitu i upadku — autorka przedstawia porządek rządzący
historią, a także udowadnia, jak ogromny wpływ na przyszłość narodu mają decyzje,
podjęte nawet w, jakby się mogło wydawać, najbardziej zamierzchłej przeszłości.
W wymienionych wyżej utworach autorka kontestuje kulturę szlachecką ${ }^{2}$ a ściślej
— formy kultury szlacheckiej. Jednoczé́nie afirmuje jej materię duchową, którą moż-

* M. J. Wielopolska, Wyrównanie, w: eadem, Danina. Cztery nowele, Przemyśl 1925, s. 44.

1 Nazwy poszczególnych okresów w dziejach Rzeczpospolitej szlacheckiej podaję za Pawłem Jasienicą.

2 Znaczenie terminu „kultura szlachecka” podaję za Januszem Tazbirem, który w swojej książce Kultura szlachecka $w$ Polsce. Rozkwit - upadek — relikty nie tylko definiuje pojęcia, ale również wyznacza ramy czasowe dla okresu w dziejach Polski nazywanego Rzeczpospolitą szlachecką: „Przez kulturę szlachecką będziemy w nim [zarysie - A. L.] rozumieć zarówno styl życia, jak i światopogląd szlachty (przede wszystkim średniej, czyli zamożnego ziemiaństwa). Styl życia znajdował swój wyraz w obyczajach, gustach artystycznych, sposobie wyposażania wnętrz. Światopogląd uzewnętrzniał się zaś $\mathrm{m}$. in. we wzorach etycznych i ideałach polityczno-ustrojowych oraz związanej z nimi kulturze 
na określić jako „szlachectwo ducha”. Historia pisana przez Wielopolską zdecydowanie nie ma znamion historii apoteozującej. Ma ona demaskować i obnażać faktyczny stan rzeczy, czyli powolny proces wewnętrznego obumierania Polski, zamaskowany narodową mitologią. Nie bez przyczyny dwa z trzech wspomnianych tekstów Wielopolskiej zostały umieszczone w zbiorze o wiele mówiącym tytule Kontryfatowe lichtarze u świętej Agnieszki. Tytułowe lichtarze stają są synonimami kłamstwa, słabości władzy królewskiej i rządów szlachty, a więc głównych chorób trawiących polskie państwo. Zamiary autorki Soboli zdradza także sam wybór przewodnika po szlacheckim „piekiełku”, a więc książki Prawem i lewem. Obyczaje na Czerwonej Rusi w pierwszej potowie XVII wieku Władysława Łozińskiego, o którym to dziele Janusz Tazbir mówi, że „po jej lekturze trudno już było uwierzyć czytelnikowi w poczciwość przodków, na którą się wszyscy admiratorzy sarmatyzmu oraz kontrreformacji tak chętnie powołują"”.

Pisarstwo Wielopolskiej i Łozińskiego łączy więc chęć demistyfikacji historii, a także stosunek do samej kultury staropolskiej, o której autor Czarnych godzin powie, wskazując na jej niebagatelne znaczenie w odniesieniu do współczesności, że granica oddzielająca dwa, jakby odmienne światy, „pozostała płynna i nie byłoby to może niewdzięczne zadanie dla historycznego badacza-psychologa: wykazać jak tej przeszłości jesteśmy już dalecy i jak jeszcze bliscy”4. Tej odczuwalnej bliskości skądinąd zamierzchłych czasów, a także szczególnemu sentymentowi do szlacheckiej przeszłości i jej ideałów Wielopolska dała wyraz w dedykacji zamieszczonej na jednej z pierwszych kart zbioru nowel Kontryfatowe lichtarze u świętej Agnieszki:

Kuzynowi mojemu Kazimierzowi Colonna-Walewskiemu z Tubądzina na znikomą pamiątkę dawnej, zaginionej przyjaźni i znajomości z przed lat — dwustu? czy trzystu? ${ }^{5}$

Podjęcie przez Wielopolską tematyki związanej z Rzeczpospolitą szlachecką mogło wynikać z jednej strony z tęsknoty za świetną przeszłością, z drugiej zaś z wewnętrznej

politycznej. [...] Rozważania swe zaczynamy [...] od epoki, w której światopogląd szlachecki występuje w swej dojrzałej postaci, a więc od czasów renesansu. Mimo wszystko jednak przedmiotem naszego zarysu pozostaje temat - morze. Jeśli bowiem ograniczymy go nawet do okresu, kiedy państwo polskie było nazywane Rzeczpospolitą szlachecką, to i tak obejmie on blisko trzysta lat naszej historii, na które przypadają ważkie epoki renesansu, baroku i oświecenia”. (J. Tazbir, Kultura szlachecka w Polsce. Rozkwit - upadek - relikty, Warszawa 1983, s. 5-6.)

3 J. Tazbir, Wstęp, w: W. Łoziński, Prawem i lewem. Obyczaje na Czerwonej Rusi w pierwszej połowie XVII wieku, w oprac. J. Tazbira, Warszawa 2005, s. 14. O Prawem i lewem Łozińskiego Aleksander Brückner pisał, że „to nie powieść, lecz mozaika spraw i sprawek, kolekcya głów warcholskich, sumień zdradzieckich, gęb niewyparzonych, pięści zaciekłych”(„Biblioteka Warszawska”, t. 252, październik 1903, s. 183).

4 W. Łoziński, Życie polskie w dawnych wiekach, Kraków 1974, s. 260.

5 M. J. Wielopolska, Kontryfatowe lichtarze u świętej Agnieszki. Nowele, Warszawa 1922, s. 5. 
niezgody na to, jak w okresie II Rzeczpospolitej tę przeszłość się wykorzystywało instrumentalnie i wręcz kłamliwie. Wielopolska zdecydowanie nie godzi się na gloryfikującą interpretację historii. Z tego też powodu autorka w swoich tekstach walczy z reliktami szlachetczyzny, pokazując, że na przypomnienie nie zasługują zewnętrzne, czysto materialne elementy kultury szlacheckiej, lecz ideały, które w założeniu miały być podstawą świata I Rzeczypospolitej. O etosie szlacheckim, który właśnie w takiej formie był szczególnie bliski autorce Napisu na furtce pisze Barbara Milewska-Waźbińska:

Obowiązki polskiego szlachcica bardzo dobrze wyraża dewiza towarzysząca idei Orderu Orła Białego: Pro Fide, Rege et Lege. Szlachcic miał za zadanie trwać w wierze przodków, bronić króla oraz przestrzegać ustalonych tradycją i prawem zasad. Rzeczpospolita przez długie wieki odgrywała rolę obrońcy chrześcijaństwa, w którą wpisana była idea antemurale Christianitatis, przez długie wieki bliska sercu szlachty. Obrona króla była z kolei konsekwencją przywileju, jakim była wolna elekcja. Każdy szlachcic mial prawo uczestniczyć w bezpośrednich wyborach króla, każdy też mógł zostać władcą, ale był również zobowiązany stawić się do walki na jego rozkaz. Jednocześnie ten sam szlachcic domagał się, aby król, za którego miał walczyć, bronił jego swobód i strzegł wolności szlacheckich. A powinien to być władca sprawiedliwy, łagodny, szczodry, ludzki ${ }^{6}$.

Jednak szczególne przywiązanie Wielopolskiej czy wręcz jej afirmatywny stosunek do etosu szlacheckiego nie oznacza, że na kartach nowel autorki Soboli znajdziemy peany na cześć przeszłości. Nie przeczytamy tu również o prawdziwym szlachectwie, którego podstawą jest cnota polegająca na „przekazywaniu z pokolenia na pokolenie nie tytułów szlacheckich, ale wartości pozwalających osiągnąć pełnię człowieczeństwa."” Wielopolska w swoich tekstach skupia się wyłącznie na ukazywaniu, w jaki sposób szlachta sprzeniewierzyła się idei szlachectwa opartej na fundamentach religijnym i etycznym, i jak takie postępowanie wpłynęło na degradację wszelkich wartości kojarzonych z prawdziwym szlachectwem. Według Wielopolskiej, agonia Polski rozpoczyna się od łamania praw i występowania przeciwko starym obyczajom, w następstwie czego zostaje osłabiona władza królewska, co z kolei prowadzi także do chaosu w sferze duchowej.

Synonimem polskiej degrengolady jest dla autorki upadek wielkich rodów. Mężczyźni, którzy powinni być przekazicielami dziedzictwa swoich przodków, nie są w sta-

6 B. Milewska-Waźbińska, Vera nobilitas. Etos szlachecki na podstawie herbarzy staropolskich, w: Etos humanistyczny, red. naukowa tomu P. Urbański, Warszawa 2010, s. 179.

7 Ibidem, s, 182. 
nie podołać obowiązkom, nakładanym na nich przez tradycję i wychowanie. Choć stoją nad przepaścią, nie mają świadomości zbliżającej się zagłady. Nie dostrzegają albo nie chcą dostrzegać prawdy o samych sobie. Wszyscy oni zamykają się w świecie atrybutów pozornej władzy i sławy rodowej, łudzą się przy tym iluzjami rzekomej wielkości i chwały. Kluczem do sfery duchowej, wyznaczającej aktywność dziejotwórczą, autorka Kontryfatowych lichtarzy czyni przeżycie, dlatego też dostęp do rzeczywistych wartości, a tym samym do prawdy mają jedynie kobiety. Dlatego też swą refleksję historyczną Wielopolska wzbogaca o kobiecy punkt widzenia, wielokrotnie pomijany przez innych autorów i porzucany na rzecz męskiego spojrzenia, przypisywanego kulturowo porządkowi historii. Przekazywany przez autorkę Soboli zapis doświadczeń przepuszczany jest jakby przez podwójny filtr. Pierwszy jego element stanowi nowe, bo kobiece spojrzenie na historię bohaterek, a także na historię powszechną. Drugi element to spojrzenie autorki. To indywidualne ujęcie nie tylko odznacza się kobiecymi atrybutami postrzegania, lecz także świadczy o gruntownej wiedzy historycznej. Ta ostatnia kompetencja umożliwia wskazanie luk, białych plam, które można, albo nawet należy wypełnić treścią, czego też Wielopolska dokonuje w swoich utworach.

\section{Dura lex, sed lex...}

Prawem i lewem Władysława Łozińskiego rozpoczyna się od swoistego lamentu nad codziennością Rzeczpospolitej szlacheckiej: „Co za świat, co za świat! Groźny, dziki, zabójczy. Świat ucisku i przemocy. Świat bez władzy, bez rządu, bez ładu i bez miłosierdzia." Z powyższego fragmentu wyłania się obraz rzeczywistości pozbawionej wszelkich „zabiegów upiększających”, odartej z narodowej mitologii, w której wizja szlachcica, postępującego zgodnie z cnotami kardynalnymi: mądrością, sprawiedliwością, męstwem i umiarkowaniem, może istnieć jedynie w sferze ideałów i na kartach dzieł dydaktyczno-moralizatorskich. Zarówno opowieść o obyczajach Rusi Czerwonej, jak kolejne teksty Wielopolskiej w takim samym stopniu burzą obraz barwnej szlacheckości. Zresztą nie bez powodu autorka Synogarlic pomysłu do kolejnych swoich utworów poszukiwała właśnie u Łozińskiego i tak samo, jak autor Legionisty, zdecydowała się odtworzyć historię codzienności Polski, a nie „historię polityczną, trzymającą się «wielkiego światła i szerokiego gościńca»" Podobny jest również sposób działania obydwojga pisarzy polegający na tym, że rozbija się mozaikowy obraz przeszłości, aby potem ze stosu drobnych, rozpryśniętych kamyczków ułożyć nową, być może prawdziwszą, bo odbrązowioną opowieść o dziejach Polski.

8 W. Łoziński, Prawem i lewem, op. cit., s. 25.

9 Ibidem. 
Nowela Sobole twórczo rozwija historię opisaną we wspominanym już dziele Łozińskiego Prawem i lewem ${ }^{10}$. Wielopolska dokonuje tu rozrachunku z prawami i obyczajami obowiązującymi szlachcica, które, choć piękne w teorii, w praktyce okazują się jedynie pustą skorupą i atrakcyjną dekoracją. W świecie opisywanym przez Wielopolską nie ma miejsca na szlachectwo, które według Bartosza Paprockiego, autora Gniazda cnoty, zasadza się na dobrych postępkach, a nie na urodzie i sile ${ }^{11}$. Tu dzieje się wręcz przeciwnie, nie patrzy się na człowieka przez pryzmat tego kim jest, ale czym jest. Stąd też tytuł utworu „sobole”, który odsyła do niezwykle drogiego elementu szlacheckiego ubioru, czyli futra. Oto prawda o cnotliwości polskich szlachciców, spadkobierców średniowiecznych rycerzy, okazuje się zupełnie inna, niż ta przekazywana w legendach herbowych. Wartości szlachectwa nie potwierdzają tu czyny, a jedynie dobre urodzenie. „Z tego też powodu — jak pisze Łoziński — czytając o ubiorach i strojach staropolskich w satyrach i pamiętnikach od XVI do XVIII wieku, odnosi się wrażenie, jakoby cała Polska była tylko jedną salą redutową, widownią zmiennej co chwila, pustej maskarady” ${ }^{2}$. I właśnie owa „pusta maskarada” staje się przyczynkiem do rozważań na temat szlachectwa, które - wyzute z wartości moralnych — opiera się jedynie na pustych formach i zwyczajach, na zasadzie kontrastu podkreślających zacofanie, ciemnotę i odczłowieczenie: „Koni było w każdej pańskiej stajni więcej, niźli tomów w jego bibliotece. Co światlejsi wiedzieli, że kaplicę sykstyńską w Rzymie, malował archanioł Gabryel." (S, 121) ${ }^{13}$.

Niezgoda na szlachectwo maski i sztucznego ornamentu widoczna jest w zachowaniu bohaterki noweli Sobole — wojewodzianki lubelskiej Beaty Firlejówny ${ }^{14}$. Wyrazem buntu staje się wygląd zewnętrzny, który, jak wspominałam, miał bardzo duże znaczenie dla polskiej szlachty, służył samookreśleniu, utwierdzał w zajmowanej pozycji. Beata swoim strojem świadomie łamie wszelkie obyczaje, wyrywając się tym samym z więżącej tradycji: „u pana Piotra Potockiego, wystąpiła panna wojewodzianka lubelska w wyciętej mocno sukni” (S, 122). Dziewczyna zdaje się prowokować swoim zachowaniem do jakiejkolwiek reakcji zebraną „brać herbową”, jednak nikt nie decyduje się na wystąpienie w obronie deklarowanych zasad. Jedyne na co stać „dzielnych

10 Zob. Ibidem, s. 203.

11 Zob. B. Paprocki, Gniazdo Cnoty, skąd herby Rycerstwa Polskiego swój początek maja, z drukarni Andrzeja Piotrkowczyka, Kraków 1578.

12 W. Łoziński, Życie polskie w dawnych wiekach, op. cit., s. 109.

13 M. J. Wielopolska, Sobole, w: eadem, Kontryfatowe lichtarze u świętej Agnieszki, op. cit. (wszystkie cytaty w tekście oznaczam literą $S$ oraz numerem strony).

14 W pierwodruku noweli opublikowanej w „Prawdzie” w 1913 roku Wielopolska popełniła błąd, nazywając wojewodziankę lubelską Marzenką, tymczasem Piotr Firlej, o którym mowa w tekście, miał sześć córek (Anna, Zofia, Agnieszka, Barbara, Beata, Jadwiga), z których żadna nie miała na imię Marzena. Ta nieścisłość zostaje poprawiona w przedruku noweli w tomie Kontryfatowe lichtarze u świętej Agnieszki, z którego to zbioru korzystam w powyższej pracy. 
mężów Rzeczypospolitej”, to potajemne szepty zgorszenia dobiegające ze wszystkich kątów sali i przerażone spojrzenia świadczące jedynie o tchórzostwie i wygodnictwie: „Głośno się gorszyć brać herbowa nie śmiała, zbyt możny był ród Potockich i Firlejów, a zresztą mówiono o pannie wojewodziance Lubelskiej, że dnie jej policzone” (S, 122). Ze swoich herbowych obowiązków nie wywiązuje się również Piotr Firlej, ponieważ w życiu prywatnym nie ma odwagi zareagować na nieodpowiednie zachowanie córki, tłumacząc swoją pobłażliwość trudną sytuacją ostatniego, ukochanego dziecka: „Woli umierającego przeciwić się nie można, więc nie przeciwił się jej rodzic, pan Piotr Firlej” (S, 123). Firlej zachowuje się tak, jak gdyby bał się córki, która, zawieszona między życiem a śmiercią, zaprzecza swoją osobą wartościom witalnym, tak bardzo cenionym przez szlachtę. Beata stanowi jakby zaprzeczenie doskonałości rodu, który, jak się okazuje, może wydać na świat istotę słabą, schorowaną, przerywającą pewną ciągłość tradycji, a tym samym naruszającą zastany porządek. Wojewodzianka świadoma swojej odmienności nie czuje się jednak z tym źle, wręcz przeciwnie, postanawia za wszelką cenę zachować swoją inność: „Była jakimś gołębiem, o trzech skrzydłach, czy jednem, jakąś sarną o błękitnych źrenicach — jakąś pomyłką natury, czy jedyną jej prawdą pośród pomyłek" (S, 127). Obrona prawa do odrębności staje się tu tym istotniejsza, że wiąże się nierozerwalnie przede wszystkim z autentycznością i szczerością, czyli z tymi cechami, których brak szlachcie. Futro z soboli szczelnie okrywające „pańskie” ciało ma symbolizować szlachecką próżność i sztuczność, natomiast nagość Beaty, łamiąca wszelkie zasady dobrego obyczaju, związana jest z prawdziwością i samoświadomością, które to cechy stają się tym widoczniejsze na tle szlacheckiej maskarady: „Tłum, zaszyty w złotogłowia, stawał się dla niej coraz bardziej tem, czem futro dla Rubensowskiej Heleny Fourment ze słynnego portretu: spotęgowaniem jej nagości” (S, 128).

Nasycony głęboką symboliką herb, który był jednym z najważniejszych elementów etosu szlacheckiego, ponieważ miał przypominać o wartościach szlacheckich, według Wielopolskiej staje się pustym znakiem, w imię którego bezsensownie odbiera się życie lub je poświęca. Teraz jest tylko ozdobą drzwi, o którą można co najwyżej rozbić „łeb”, a nie dewizą prawdziwego szlachectwa: „Sulatycki runął na wznak, łeb odbił mu się o czarny marmur drzwi, o jakiś zagadkowy labr Firlejowskiego herbu i zesunął się na podłogę" (S, 131). Wielopolska udowadnia, że powieściowy ideał szlachcica naprawdę nie istnieje; po świetnej przeszłości nie pozostały zasady, a jedynie stare pamiątki, którym oddaje się uświęcającą cześć: „Blachą srebrną powleczone stoły, zamczyste skrzynie, zegary, przez szacunek nigdy nienakręcane, wszystko to czyniło salę małą, nabitą, ścieśnioną" (S, 125).

Wojewodzianka egzystuje w ciągłym zagrożeniu, otacza ją przemoc i gwałt, a mimo to pozostaje chłodna, silna i bezwzględna. Beata nie żyje ideałami, twardo stąpa po ziemi, nie daje się uwieść złudnemu blichtrowi otaczającego ją świata. Postawa dystansu daje jej komfort przyglądania się maskaradzie z boku, a jednocześnie pozwala w dowolnie wybieranych przez siebie momentach obnażać głupotę, prostactwo i kłamliwość 
zebranych. Nikt jednak nie rozumie Firlejówny, ponieważ nikt nie potrafi, tak jak ona, wyjść z przypisanej sobie roli. Dziewczyna skutecznie broni się przed nakładaną na nią maską, wyrywa się ze strefy osobistego zagrożenia i, balansując na granicy światów, broni swojej nietykalności ${ }^{15}$ i odrębności. Cena, jaką przychodzi zapłacić za przywilej wolności, nie gra roli: „Pan Lasocki zmarszczył brwi. Trochę niesmaku, trochę niezaradności zabłysło w jego oczach: [...] za drogo go kosztował, Beatko, ten zaszczyt tańczenia z tobą..." (S, 131). Pan Lasocki nie rozumie i nie może rozumieć zachowania Beaty, zbyt mocno tkwi w szlacheckiej obyczajowości. Dziewczyna, skazując na śmierć młodego dworzanina z pozornie błahego powodu, jak zakazany taniec, dokonuje ostatecznej demistyfikacji tradycji szlacheckiej, wskazując także na jej niekonsekwencję i płytkość. Szczęsny Sulatycki nie ginie dlatego, że postąpił wbrew przyjętym obyczajom i naraził na zniesławienie córkę magnata, ale dlatego, że zebrani oficerowie zazdroszczą mu odwagi i zdecydowania. Tradycja staje się tu tylko wygodną przykrywką dla zaspokojenia męskiej ambicji i dumy: „Błazen jesteś! — plunął mu w twarz. Myśmy oficerowie, a przecież nie śmieliśmy prosić do tańca pannę wojewodziankę" (S, 130). Natomiast zebrani magnaci nie reagują zupełnie na nieobyczajny taniec, który, zważywszy na skąpą suknię wojewodzianki, ma charakter niezwykle erotyczny. Nawet Piotr Firlej nie zachowuje się w tej sytuacji odpowiednio, ale, zgodnie ze słowami Łozińskiego, dziwnie: „Jegomość pan Firlej, rodzic panny wojewodzianki, z onego skromności i przystojnego postępku kontent zostawal"16. Postępowanie magnata, któremu trudno było zaakceptować suknię córki, godzi się natomiast na zmianę czy też złagodzenie obyczajów związanych z różnicami stanowymi, ociera się o hipokryzję. Wojewoda lubelski nie wie tego, co Beacie wydaje się jasne — że największe zagrożenie tkwi właśnie w odstępowaniu od starych praw, a nie tych, wynikających z chwilowej mody.

Wielopolska nie daje się złapać w pułapkę mitu Złotego Wieku. Postępujący rozkład starego prawa i zasad doprowadza w rezultacie do osłabienia fundamentów państwa polskiego. Sytuację kryzysową wywołuje postępujący relatywizm moralny, który wpływa na zastępowanie wartości duchowych wartościami materialnymi. Jednak głównym problemem wydaje się wyczerpywanie formuły męskości, które doprowadza do upadku wielkich rodów, a następnie całego państwa, w wyniku rozpadu silnej władzy królewskiej.

\section{Augustus mortuus est, habemus novum Augustum!}

Do obowiązków szlachcica, jak już było wspominane, należała wierność królowi i bezwzględne posłuszeństwo, a w razie zagrożenia ratunek przed wrogiem i pomoc w jego

15 Zob. G. Borkowska, Cudzoziemki. Studia o polskiej prozie kobiecej, Warszawa 1996, s. 221-222.

16 W. Łoziński, Prawem i lewem, op. cit., s. 203. 
odparciu. Sam monarcha natomiast był kreowany na pierwszego szlachcica Rzeczypospolitej, którego powinna charakteryzować lagodność, sprawiedliwość, szczerość, męstwo, laskawość i dobrotliwość ${ }^{17}$. Maria Wielopolska w noweli Kontryfatowe lichtarze u świętej Agnieszki ukazuje rozpad tego wzorca, który spowodowany jest z jednej strony zachowaniem szlachty godzącym w system zobowiązań względem korony, z drugiej zaś postępowaniem samego króla wybierającego prywatę i realizującego jedynie własne zachcianki. Autorka w tekście ukazuje słabość władcy, który nie jest w stanie pełnić swych funkcji, gdyż ulega podszeptom dworzan i kolejnych kochanek. Zaplątany w sieć intryg nie może wyzwolić się spod panowania dwóch kobiet — dopiero co zmarłej Barbary Radziwiłłówny i Barbary Giżanki, mieszczki do złudzenia przypominającej nieżyjącą królową. Wielopolska zdecydowanie oddaje tu głos kobietom — mężczyźni stają się jedynie dopełnieniem, istnieją właśnie dzięki nim.

Patrząc na Zygmunta Augusta oczyma Wielopolskiej widzimy człowieka schorowanego, uciszającego ból fizyczny i przede wszystkim psychiczny dziwnymi miksturami ziołowymi: „Miesza król tajemne zioła w swoim złoconym roztruchanie, trybowanej roboty. Łyżka Barbary z jej ulubionym napisem: «Serce bezpieczne: wesele wieczne"... dzwoni metalem o metal»" (Kl, 17). Zagłuszeniu cierpienia nie służą tu tylko podejrzane leki, ale także pamięć o ukochanej żonie i jej wspomnienie, które działają lepiej niż narkotyk. Zygmunt August pielęgnuje ten zapiekły ból używając przedmiotów — w tym wypadku łyżki — należących do Barbary, traktując je jednocześnie jak relikwie. Wielopolska ukazuje Zygmunta Augusta balansującego na granicy życia i śmierci, rozpiętego między dwiema kobietami będącymi synonimami królewskiego istnienia pomiędzy światami, mówi o tym Giżanka: „Jestem Izis-Poczęcie, Izis-Życie, Izis-Olśnienie, Izis-Dur. Tak jak ONA się stała Neftys-Zgon, Neftys-Kres, NeftysZamroka" (Kl, 16).

Choć wizerunek ostatniego Jagiellona, który rysuje się w noweli Kontryfałowe lichtarze u świętej Agnieszki, jest niezwykle przejmujący i ważny, ponieważ w gruncie rzeczy jest symbolem umierającego państwa, to jednak znacznie więcej uwagi Wielopolska poświęca Barbarze Giżance dopowiadając to, co sama historia dotychczas przemilczała. Giżanka jawi się nam nie jako ofiara, choć musi zrezygnować ze swojej osobowości i udawać kogoś, kim nie jest, ale jako osoba lubiąca grać pewną siebie, inteligentną kobietę i dzięki temu wygrywać. Co ważne, oglądamy ją nie jak dotychczas oczyma innych, głównie mężczyzn, ale oczyma jej samej, uzyskując dzięki temu nowe ujęcie tematu tak chętnie podejmowanego przez pisarzy i historyków. Giżanka prezentuje się tu jako kobieta niezwykle silna i świadoma swych możliwości, a przede wszystkim wykorzystująca swoją wiedzę i zręczność dla własnych celów. Dla niej nie są ważne bogactwa, to jedynie dodatkowa korzyść, najistotniejsze są świadomość gry i smak wygranej:

17 Zob. J. Tazbir, Kultura szlachecka w Polsce, op. cit., s. 69. 
Nieprzytomny jesteś. Na to liczyli oni, dworska twoja polewka. Ja nie. Pragnęłam świadomości twojej, aby zwycięstwo gry mojej było najświetniejsze. Całe moje szalone serce jest w tej grze, jak rubinowa oś $(\mathrm{Kl}, 10)$.

Królewska faworyta jest wytrawną hazardzistką, która za wszelką cenę dąży do wyznaczonego przez siebie celu. Gotowa jest na wszystko, nawet na dokonanie niemożliwego, czyli wskrzeszenie umarłej i wypełnienie treścią tego, co dawno już utraciło swoje znaczenie:

Przywiódł mnie pan starosta lwowski, abym z szat i giezeł umarłych, pleśnią pachnących - z pereł, z których treść wyssano, z rubinów, które się stały cieliste pod ziemią, wykrzesała życie podwójne: Jej życie i swoje $(\mathrm{Kl}, 11)$.

Wyrafinowana tresura, której poddaje siebie samą Giżanka, ponieważ wie, że musi przejść trzy próby: wyglądu, głosu i gestów, ostatecznie kończy się sukcesem. Kobieta, niczym pajęczyca, oplata Zygmunta swoim czarem ukradzionym Radziwiłłównie.

Król zamiast życia wybiera ułudę i trwanie wśród wawelskich katakumb. Rzeczywistość zostaje tu zastąpiona ciągłą rozgrywką, maskaradą, której władca przygląda się za pośrednictwem lustrzanego odbicia, aby w ten sposób oszustwo uczynić bardziej znośnym: „Król patrzy nie na nią, ale na jej odbicie w lustrach. Jest mu bliższą prawdy w tem kłamstwie lustrzanym” (Kl, 17). Nawet czas nie płynie tu w tradycyjny sposób, gdyż odmierzany jest wspomnieniami zmarłej królowej, bez której pogrążony w gorączkowych majakach Zygmunt August nie umie żyć — i z tego też powodu jej cień jest ciągle przy nim: „Zachowałem ją we wszystkie dwanaście godzin! w każdej minucie szukałem jej zagubionej bliskości. Klucz do jej duszy, tak jak do jej trumny, leży u mnie na sercu nieutulonem" (Kl, 18).

Jednak wbrew temu, co sądzi o sobie ostatni z Jagiellonów, jego egoizm i neurotyczność sprawiają, że traci on nawet to, co jest dla niego najdroższe, a więc ów „klucz do duszy” Radziwiłłówny. Król jest tak słaby psychicznie, że nie ma prawa do kobiety prawdziwie silnej, która wykazuje się większą odwagą niż on, mężczyzna. Uświadamia mu to Barbara, która na temat ostatniej żony Zygmunta zdaje się wiedzieć więcej, niż on sam. Giżanka przeżywa w pewnym sensie porozumienie dusz z Radziwiłłówną, patrzy na młodą królową z kobiecej perspektywy, rozumie ją, gdyż sama jest kobietą, a w tym wypadku wspólnota przeżyć okazuje się kluczowa:

Tylko ciało! trzykroć święte, trzykroć uwielbione od wieków i po wieki!!! [...] Nikt ich nie zrozumiał. Nawet ty. Wtedy na przykład, kiedy się ONA wydawała najpokorniejszą, rezygnując uporczywie z sąsiedztwa prochów królewskich, wtedy właśnie była najtwardszą, wtedy właśnie 
JEJ wola przełamywała wolę braci — pysznych knieziów i nienasyconość wielmożnego rodu (Kl, 19-20).

Młoda warszawianka obnaża tu największe królewskie słabości, a więc małostkowość i pożądliwość, które zamknęły mu drogę do duszy ukochanej żony. Według Giżanki stało się to szczególnie widoczne w sytuacji próby, a więc śmierci Barbary, kiedy to władca nie był w stanie wznieść się ponad męską pychę. W sytuacji, w której urażona została jego duma, nie potrafił uszanować poświęcenia młodej królowej, ponieważ nie rozumiał go, jakby nie widząc, że gest poniżenia, który wykonała Barbara rezygnując z pochówku na Wawelu, był prawdziwie królewskim i godnym zajmowanej przez nią pozycji:

Och, królu! a tyś się mścił raczej, niźli JEJ tęsknoty słuchał. [...] Nie ukląkłeś przed JEJ męką i zwycięstwem. Nie roztkliwiłeś się nad jej dziecinnym stchórzeniem. Szkoda, królu. Byłbyś JĄ niósł z jeszcze większym przepychem, poprzez całą Polskę, do Wilna! (Kl, 21).

Giżanka dużo więcej widzi i wie niż sam władca, choć ten traktuje ją i to, co mówi, z przymrużeniem oka: „Filozofie miły... — uśmiecha się król blado do jej uczoności” $(\mathrm{Kl}, 18)$. To królewska faworyta, prosta mieszczka, a nie posiadający świetne wychowanie Zygmunt August, rozumie, że nie należy łamać tradycji, a na królu ciążą szczególne obowiązki, ponieważ nie odpowiada tylko za siebie. Dlatego też prawdziwy władca powinien być roztropny i twardy, a nie lekkomyślny i sentymentalny.

Dopiero w przededniu śmierci Zygmunt August wyrywa się z koszmarnego snu i dotyka rzeczywistości. To, czego dotychczas nie chciał poznać — prawda, staje się dla niego oczywiste. Swoją słabość Jagiellon przełamuje ostatnim, przedśmiertnym gestem mającym zamaskować nieudolność i prywatę w sposobie sprawowania władzy, których symbolem stają się kontryfałowe lichtarze:

Potem zamyśla się i prosi nareszcie głosem prawie że obojętnym, aby ksiądz kapelan wziął ze skarbca dwa srebrne lichtarze i oddał je u P.P. Klarysek na Stradomiu, w miejsce kontryfałowych, które z ołtarza świętej Agnieszki usunąć należy. - Usilnie polecam - kończy król dość niejasno $(\mathrm{Kl}, 26)$.

Zygmunt August wydaje więc ostatni, jeden z niewielu prawdziwie królewskich rozkazów, w którym jest siła i zdecydowanie. Jednak na to jest już za późno, zmiany wywołane przez nieprzemyślane posunięcia króla są nieodwracalne, słowa Zygmunta, tak jak on sam, przestały już znaczyć. Nikt nie wypełni woli ostatniego z Jagiellonów. Jak pokazuje Wielopolska, klęska króla jest całkowita, ponieważ nawet w chwili konania 
nie doznaje on laski prawdy. Pojawia się tu również refleksja na temat samej historii. Autorka pokazuje nam, że historia, którą znamy, jest w rzeczywistości ciągiem nieporozumień, maskarady i błędnych interpretacji. Dlatego też nigdy nie poznamy prawdy, tak jak nie znał jej ksiądz Kłodawski towarzyszący w ostatniej drodze królowi: „Ale znowu się rozmarza zgrzybiała twarzyczka księdza pocieszającem mniemaniem, że te słowa są niezaprzeczonem świadectwem skruchy i żalu za pomyłki królewskiego żywota” (Kl, 27). Cała opowieść kończy się gorzką pointą:

Lichtarzy nigdy skarbiec królewski nie wymienił. Dopiero jejmość panna Barbara Giżanka wymieniła je na srebrne, w dniu zaślubin swoich z kneziem Wiśniowieckim. Ale śpią spokojnie kości najwielmożniejsze $(\mathrm{Kl}, 28)$.

Po co Giżance lichtarze? Być może stanowiły swoiste trofeum, a może dowód na to, że bez względu na wysokość stawki w grze, ona zawsze tylko imitowała Barbarę Radziwiłłównę, tak jak cyna srebro.

\section{Bóg mi powierzyt honor Polaków, Jemu go tylko oddam}

W utworze Napis na furtce Wielopolska ukazuje rzeczywistość rozbiorową widzianą zarówno oczyma ludzi zwykłych, jak i tych należących do królewskiej świty. Dzięki temu podwójnemu widzeniu obnażona zostaje małostkowość i hipokryzja dworu, wywyższony natomiast wzór szlachcica-ziemianina, prostego i szczerego człowieka żyjącego z pracy własnych rąk. To właśnie jemu, wiejskiemu prostaczkowi dane jest prawdziwe poznanie historyczne, które staje się możliwe dzięki przeżyciu, a nie rozumowaniu i logicznym uogólnieniom. Doświadczanie historii przybiera tu postać nagłego objawienia odsłaniającego prawdę o przeszłości ${ }^{18}$.

Tekst noweli otwiera opis polskiej wiosny, wyjątkowej pory roku, w której świat na nowo budzi się do życia, zapowiada wielkie zmiany i przynosi nadzieję nieszczęśliwemu narodowi. Wielopolska dodatkowo wzbogaca to znaczenie, nazywając „Wiosenką” kobietę, dzięki której dokona się odrodzenie ducha narodu. Teresa, młoda szlachcianka nazywana „Wiosenką”, zostaje tu utożsamiona z naturą: „Myślałem, żeś sama tu, Wiosenko, jak przystało na królowę sadów kwitnących. [...] Że sama tu panujesz, w kwiaty się strojąc i karmiąc się tylko ich miodem, jak pszczoła..." ${ }^{19}$ (Nnf, 114). Jej świeżość i nieskażona przez wielkomiejską cywilizację prostota zostają skontrastowane ze zmanierowaniem i pustotą młodego księcia Józefa Poniatowskiego i podkomorzego

${ }_{18}$ Zob. F. Ankersmit, Jezyk a doświadczenie historyczne, przeł. S. Sikora, w: idem, Narracja, reprezentacja, doświadczenie. Studia z teorii historiografii, pod red. E. Domańskiej, Kraków 2004, s. 223.

19 M. J. Wielopolska, Napis na furtce, w: eadem, Synogarlice, Warszawa 1915 (wszystkie cytaty w tekście oznaczam Nnfi numerem strony). 
Stanisława Trembeckiego: „tylko dwaj panowie szli nad rzeką, prawie milcząc, cudacznie, a wspaniale postrojeni, bez szczególnego zachwytu patrząc na rozległą panoramę" (Nnf, 112). Przyzwyczajeni do sztucznego przepychu i cudzoziemszczyzny, nie potrafią już zachwycać się rodzimym krajobrazem: „Powinieneś odę napisać na cześć wiosny, o ile cię inspirować potrafi ten mydlany [pejzaż - A. L.]" (Nnf, 112). Wielopolska krytykuje tutaj osiemnastowieczne elity intelektualne, do których niewątpliwie można zaliczyć dworzan Stanisława Augusta Poniatowskiego. Królewscy zausznicy biorą udział w zbiorowej maskaradzie, która polega nie tylko na przebieraniu się zgodnie z zagranicznymi trendami, lecz także na maskowaniu istniejącej sytuacji politycznej. W atmosferze ciągłej gry i maskowania słów werbalizacja doświadczenia historycznego okazuje się niemożliwa. Demistyfikacji może dokonać jedynie Teresa, która kieruje się w życiu wyłącznie uczuciem i emocjami, odrzucając sztuczność konwencji. To właśnie ta prosta dziewczyna de-intelektualizuje język, pokazując rzeczywistość i jej prawdziwe, pozbawione maski pozorów oblicze:

— Wiosenko! Wiosenko! to ty wiesz, kto kogo zabił w roku 1392-im, a nie wiesz, że Stanisław August Poniatowski jest od piętnastu lat nie żadnym stolnikiem litewskim, ale polskim królem?!

— Polska nie ma króla, — odrzekła chmurnie i sucho (Nnf, 114-115).

Brak zaufania do języka Wielopolska podkreśla również, wkładając w usta Teresy słowa o śmierci poezji. Język poetycki, jako odświętna forma języka praktycznego będący uprzywilejowanym narzędziem poznania i kreowania rzeczywistości, zostaje tu ośmieszony, a następnie zanegowany:

— Dziaduś twierdzi, że umarła polska poezja — spojrzała niedowierzająco — I polski honor. [...] ...że poeta, to anioł i święty, bo natchnienie od Boga pochodzi — a jakże mogą być aniołowie w owym piekle, gdzie się co dzień Ojczyznę sprzedaje za carskie czerwieńce? (Nnf, 115).

Dla Wielopolskiej prawdziwy język będzie związany ze szczerością, ze słowami pozbawionymi maski i wypełnionymi treścią, dlatego też zostaje tu zanegowana poezja dworska uprawiana przez Trembeckiego. Słowa na usługach zaborcy, rosyjskiego sprzedawczyka, przestają znaczyć. Poeta dworski nie jest w stanie podołać zadaniu przygotowania duchowego zwrotu, będącego warunkiem powrotu świętości i ponownego objawienia się ludziom „zbiegłych bogów”20. Nic nieznaczącej twórczości Stanisława

20 Zob. T. Kunz, Trwanie poza poezją, „Znak” 2011, nr 677, s. 1. Należy zaznaczyć, że Tomasz Kunz, pisząc o „zbiegłych bogach”, wykorzystuje stwierdzenie Martina Heideggera. 
Trembeckiego zostają przeciwstawione dydaktyczne i moralizatorskie dzieła Andrzeja Frycza-Modrzewskiego.

Wychowanemu za granicą młodemu księciu początkowo niedostępne jest to, co dostrzega i intuicyjnie wyczuwa Teresa: „—Kto ojczyznę sprzedaje, bój się Boga, Wiosenko?! — Pan stolnik litewski i jego zausznicy" (Nnf, 115). Wielopolska, łącząc na kartach swojej noweli tych dwoje młodych ludzi, przekonuje po raz kolejny, że w odczytaniu historii nie liczy się rozumowe postrzeganie rzeczywistości, ale przede wszystkim autentyczne przeżycie. Młoda szlachcianka ma to, czego brakuje księciu, a więc świadomość narodową, z której wypływają miłość i poczucie przynależności do ojczyzny i zakorzenienie w jej historii. Z przedziwnego snu zapomnienia wybudza księcia Józefa dopiero Teresa, która uświadamia mu przede wszystkim jego bezdomność i pozorność otaczającego go dworskiego świata. Przemianie księcia towarzyszy symboliczna scena poprowadzenia na wzniesienie, z którego widać całą okolicę, a więc droga ku górze. W zakończeniu utworu pojawia się natomiast szczegółowy opis skoku księcia w rwące nurty Elstery. Jego ziemską wędrówkę zakończy zatem zejście w dół. Ta klamra spinająca tekst, oparta na opozycji góra — dół, przywodzi na myśl misteryjne obrzędy ${ }^{21}$. $\mathrm{Z}$ tego też powodu wydarzenia te można traktować jako rodzaj inicjacji, przekroczenie granic dotychczasowej podmiotowości poprzez spotęgowanie wzruszeńn ${ }^{22}$ lub rytualną zmianę statusu. Dzięki Teresie w młodym księciu budzi się poczucie obowiązku wobec ojczyzny i poczucie przynależności do narodu polskiego, książę Józef staje się świadkiem odrodzenia wyniszczonego społeczeństwa polskiego ${ }^{23}$. Proces odzyskiwania pamięci i wzrastania oraz przygotowywania się księcia do nowej roli społecznej i narodowej symbolizuje postać siewcy, którego przy pracy obserwuje Poniatowski:

Bliżej, na brunatnym, rozoranym zagonie szedł chłop i pięknym, mocnym, szlachetnym giestem siał zboże — smugę czyniąc ziarnem dookoła siebie, tak że chwilami wyglądak, jak toczący się zawrotnie bąk-olbrzym (Nnf, 117).

Uświadomienie księciu jego miejsca w otaczającym go świecie związane jest z odczuciem dotknięcia rzeczywistości, którego młody pan doświadcza w podwarszawskich Jordanowicach. Józef przeżywa spotkanie z historią swojego kraju, które, choć krótkotrwałe i chwilowe, odmienia całe jego życie:

${ }^{21}$ Zob. S. Brzozowska, Człowiek i historia $w$ dramatach Tadeusza Micińskiego, Opole 2009, s. 123.

22 Zob. F. Nietzsche, Narodziny tragedii, czyli hellenizm i pesymizm, tłum. L. Staff, Kraków 2003, s. 21.

${ }^{23}$ Zarzucany księciu w czasach rozbiorów i powstania kościuszkowskiego arystokratyczny kosmopolityzm został w okresie Księstwa Warszawskiego radykalnie przedefiniowany. Jak zauważa Sabina Brzozowska: „legenda bohatera mogła posłużyć się motywem przemiany grzesznika: od «salonowego Pepi» i libertyna «spod Blachy» po «dziedzica tradycji hetmańskiej»". (S. Brzozowska, op. cit., s. 120). 
Popiół żalu posypał cały krajobraz, tak bardzo przecież słoneczny! smutek się tłukł od zagród do lasu, od lasu do rzeki, niby bezdomny pies. Snuła się tęsknota niepokonana za czymś, co tylko tej ziemi było wiadomym, i potrącała o drzewa że wydawały dźwięk, inny niż wszędzie. Nigdzie tak drzewa nie szumią, jak w Polsce. Trochę w tym szumu proporców, a trochę jęku — pogrobna pieśń dla heroja (Nnf, 117-118).

W powyższym fragmencie widać, że bohater doświadcza tego typu doznania historycznego, o którym Frank Ankersmit napisze, że:

Towarzyszy temu ponadto poczucie, jak gdyby przestrzeń zyskała nagle dodatkowe wymiary, inna świadomość kolorów i, powiązana z tym, tendencja do synestezji, w której całościowość doświadczenia zmysłowego powoduje przelewanie się doznań z jednych zmysłów na drugie ${ }^{24}$.

Wyjątkowość Teresy sprawia, że ma ona bezpośredni dostęp do zgasłej już przeszłości: „To szlacheckie nazwisko, waćpanowie. [...] Teodor Wiosna, łowczy króla Władysława Jagiełły, zginął pod Witebskiem roku 1392. Świdrygiełło go zabił” (Nnf, 113) i dzięki temu darowi nie tylko wyrywa księcia ze stanu „zbiorowej amnezji”, ale także nie pozwala mu ulec atrakcyjnej sile kolejnej kreacji — smutnego mściciela ojczyzny, szaleńca skazującego się na śmierć:

Może usarzem zechcesz być, paniczu? — uśmiechnęła się na pół smutno, na pół ironicznie. [...] Nie sztuka, nie sztuka umierać, — zaprzeczyła żywo.

— Dziaduś powiada, że tylko żyć sztuka, dla ojczyzny (Nnf, 118-119).

Świat, z którego zostaje wyrwany młody książę, jest światem bez historii, gdzie liczy się jedynie aktualny stan rzeczy, gotowy do powielania schemat zachowań i sądów. Teresa umożliwia księciu poszerzenie samoświadomości, czy wręcz jej odzyskanie: pełne rozumienie siebie i swojego świata, tego prawdziwego, gdzie język działa demaskatorsko, a nie fałszująco. Szlachcianka przekazuje Józefowi swoje doświadczenie, następuje tutaj to, co pozornie jest niemożliwe, a więc przepływ jednego strumienia świadomości do innej świadomości ${ }^{25}$. Teresa, przekazując księciu swoje doświadczenie, które przywraca nie tylko przeszłość, ale także demistyfikuje teraźniejszość, rozbudza w nim poczucie obowiązku względem ojczyzny. Odzyskana tożsamość jednostkowa pozwala

${ }^{24}$ F. Ankersmit, op. cit., s. 228-229.

${ }_{25}$ Zob. P. Ricoeur, Jęzłk, tekst, interpretacja, wybór i wstęp K. Rosner, przekł. P. Graff i K. Rosner, Warszawa 1989, s. 84-85. 
księciu dostrzec pewną zależność, w myśl której przeszłość i teraźniejszość warunkują przyszłość. Fragmentaryczność i niepełność zostają zastąpione ciągłością, czas linearny ustępuje miejsca cyklicznemu, wpisanemu w święty porządek natury rodzenia się i umierania. Dzięki odzyskanej pamięci książę zostaje wpisany, czy nawet sam wpisuje swoje życie w dzieje narodu, odnajdując powołanie, a także w nagłym doznaniu uświadamiając sobie przyszłość: „—A jeśli mi kiedy ojczyzna swój honor powierzy, komuż będę go mógł oddać, jak nie samemu Bogu?! Więc trzeba będzie umrzeć” (Nnf, 119). Dzięki konfrontacji ,ja — ty” książę odkrywa siebie. Przeglądając się w Teresie, niczym w lustrze, dostrzega swoje prawdziwe oblicze odarte z maski. To nagłe oświecenie sprawia, że młodzi na chwilę zamieniają się miejscami, książę doznaje łaski widzenia tego, co nawet dla Teresy okazuje się ukryte; ukazuje mu się duch narodu w jego prawdziwej postaci: „Blask klingi tak łatwo wziąć za blask łez!! I to jest w nas... Trzeba się strzec pomyłki” (Nnf, 119). W noweli Napis na furtce Wielopolska wykazuje wyższość doświadczenia historycznego opierającego się na wspomnieniu, nad tym, które bazuje na dokumentach. Świadectwo ludzi zanurzonych w historii, jak Teresa, okazuje się trwałe i niezacieralne. Historia, która opiera się wyłącznie na aktach, sprawozdaniach i służbowej dokumentacji lub na ekonomicznych raportach, handlowych rewersach, statystykach, tabelach i wykresach, jest niema i głucha na los człowieka ${ }^{26}$. Okazuje się, że trwałe jest właśnie wspomnienie, a nie zapis, który, tak jak tytułowy napis na furtce, zanika zatarty przez czas: „Deszcz, śniegi i szrony zabliźniły rany liter, wśród szmaragdu mchów i zmurszenia, żaden się już napis mglisty nie znaczył. Zatarł czas wszystko” (Nnf, 122). Teresa doświadcza szczególnej łaski, na wiadomość o śmierci księcia Józefa Poniatowskiego przypomina sobie jego słowa nareszcie rozumiejąc ich sens i wykorzystując zawartą w nich naukę:

Płakali, twarz zakrywszy, tylko pani Teresa oczy miała suche, pamiętając może, że ON jej powiedział, 35 lat temu: — „Nie płacz jest w nas, ale surma bojowa. Blask klingi tak łatwo wziąć za blask łez!... Trzeba się strzec pomyłki”(Nnf, 123).

Przywołując historię młodego księcia, Wielopolska, wprowadziła tę barwną i niejednoznaczną postać w szerszy plan — w kontekst mitu odrodzenia Polski poprzez ofiarną śmierć bohatera. Jednak, aby prawidłowo odczytać sens poświęcenia, trzeba, według Wielopolskiej, wyzwolić się z mielizn narodowej mitologii, z historii, która nie gwarantuje nieśmiertelności, a jedynie smutek i zapomnienie, a na takie odczytanie może pozwolić sobie jedynie kobieta wpisana w święty porządek natury.

${ }_{26}$ Zob. G. Gajewska, Dotkną́ przeszłości. Kilka uwag na temat różnych form doświadczenia historycznego, „Kultura i Historia” 2003, nr 5, s. 3. 
Wielopolska spogląda na historię z dystansu czasowego, prowadzi czytelnika ku doświadczeniu wydarzeń bardzo dalekich, tak dalekich, że ów dystans czasowy lagodzi nawet najbardziej dramatyczne wydarzenia. Autorka, niczym prawdziwy badacz, próbuje pozbierać i oswoić okruchy „tamtego” świata w taki sposób, by stały się one częścią współczesnego doświadczenia. Wielopolska proponuje bardziej naiwny sposób odczuwania historii. Chodzi w nim o „uchwycenie sacrum zanurzonego w czasie, w czasie, którego postęp nie rujnuje, w którym wszystkie lata się łączą"27.

\section{Anna Lewenstam \\ "My nie jesteśmy: ty i ja. My jesteśmy czegoś katastrofalną tylko konsekwencją" ['We do not exist: you or me. We are only a consequence of something catastrophic']. Maria Jehanne Wielopolska writes a history of women}

Virginia Woolf said in 1927 that women should finally write the history from the beginning, because this one already written is seen from the male perspective and, in fact, is the history of men. In such history there is no space for women. In the later feminist research even a deconstruction of the very word history — understood as his — story (his history/story) — was proposed, and a replacement by a word herstory (her history/story).

The article deals with the history written, as if, from scratch, which gives voice to the mute participants of events. Therefore, women are made the foreground figures of history. The text refers to contemporary feminist researchers, undertaking the problem of female historiography, such as Joan Kelly, Joan W. Scott, Natalie Zemon Davis, or Ewa Domańska.

The protagonist of these considerations will be Maria Wielopolska, a writer working in the late of the $19^{\text {th }}$ and $20^{\text {th }}$ centuries, whose reflections about women and their place in the world turn out to be very modern. Breaking with conventions of writing history in which a key role is played by men, Wielopolska shows women who have an impact on the course of history, but also, and perhaps above all, on the fate of the men presented in the background of a great history. The author in her texts depicts domineering women, with strong characters, who can be just as dangerous, violent and torn by passions, like men. Her heroines are very often determined and ready to fight for what is their own at all costs: "patrycyuszki zwodne, renesansowe duchessy, [...] dusze jagnięce, białoruniste i krogulcze" ['tricky noblewomen, Reneissance duchesses, [...] the soul of lambs, white fleeced, and hawked'] — as the author calls them. There are no embarrassing issues for Wielopolska - women's body, sexuality, brutality of men, unwanted marriage, duplicity of the secular and ecclesiastical authorities, political games - these are the problems that are touched by the author, totally ignoring public criticism, as well as social and cultural taboo.

The aim of the article will be to present the work of this very modern and brave writer with a focus on a specific philosophy of history, which she managed to create in the works devoted to women and their history.

27 P. Ariés, Czas historii, tłum. B. Szwarcman-Czarnota, Gdańsk 1996, s. 44. 